\title{
Nuclear control of early embryonic development in domestic pigs
}

\author{
R. S. Prather \\ Department of Animal Sciences, University of Missouri-Columbia, Columbia, \\ MO 65211 USA
}

In mammals, growing oocytes have characteristically high levels of RNA synthesis. After the initiation of meiosis, that is germinal vesicle breakdown, this RNA synthesis ceases. Although there is limited evidence for RNA synthesis by the zygote, significant amounts of RNA synthesis do not occur until a species-specific cell stage. In pigs, significant amounts of mRNA synthesis cannot be detected before the four-cell stage. There appear to be three qualitatively different periods of transcription during the four-cell stage. The first occurs during a short $(<2 h) \mathrm{GI}$ phase. The second, occurs after completion of DNA synthesis ( $\mathrm{S}$ phase) about $16 \mathrm{~h}$ after cleavage to the four-cell stage, and the third occurs about $24 \mathrm{~h}$ after cleavage to the four-cell stage. Correlated with these changes in RNA synthesis are changes in nucleolar morphology, amino acid transport characteristics, protein production, mitochondrial morphology, and metabolism of the embryo. The mechanisms that regulate initiation of RNA synthesis in early mammalian embryos appear to repress transcription. A state of transcription permissiveness then follows that sets into motion the differentiation programme.

\section{Introduction}

A complete understanding of the molecular events that occur during embryogenesis is essential not only for reducing the loss of conceptuses, but also for its application to newly emerging biotechnologies, such as cloning by nuclear transfer, production of transgenic animals, manufacture of chimaeras and in vitro maturation, fertilization and development. Early mammalian development has been best characterized in mice. This is largely due to economic considerations, such as costs of animals, housing, and superovulatory drugs. In addition, the supply of embryos from other species is limited by low ovulation and conception rates as well as long generation intervals. The mouse model has been valuable for providing direction for initial studies in other mammalian species; however, as will be discussed, it falls short of providing a sound basis of information for pigs. Previous reviews have focused on the mouse model and provided a species comparison (Prather and First, 1988; Telford et al., 1990); this review will focus on molecular events that occur during embryogenesis in mice and pigs with a comparison with other species where appropriate.

Development of pig embryos immediately after fertilization is independent of embryonic mRNA synthesis. During the four-cell stage, the pig embryo first begins to produce significant amounts of mRNA. As the embryo develops to the blastocyst stage, a variety of metabolic changes occur that result in the establishment of the primary tissues. The first nuclear events probably establish the entire differentiation programme and may be partially responsible for the asynchrony seen in development at elongation. Thus these early differentiation events may have a profound influence upon embryonic survival. 


\section{Early Embryonic Cell Cycles}

The duration of early embryonic cell cycles has previously been determined by collecting embryos at various times after the onset of oestrus or after hormonal stimulation. The rationale for this type of experimental design was the inability of zygotes placed in vitro to develop beyond the four-cell stage, i.e. they stopped developing or 'blocked' at the four-cell stage (Davis, 1985). Culture conditions have been described that permit development from the zygote to blastocyst (reviewed by Reed et al., 1992; Petters, this supplement). Pig embryos do not seem to be sensitive to glucose or phosphate (Hagen et al., 1991; Petters et al., 1990) as are the embryos of hamsters (Schini and Bavister, 1988), mice (Chatot et al,, 1989) and cattle (Ellington et al., 1990). Our studies used Whitten's medium to obtain high rates of development of zygotes to the blastocyst stage. Beckmann et al. (1990) showed development to term of zygotes cultured to blastocyst in Whitten's medium.

The duration of the early cell cycles might be regulated by the swine leucocyte antigen (SLA) haplotype. This gene is similar to the preimplantation embryonic development (PED) gene in mice which maps to the $\mathrm{Qa}-2$ region of the major histocompatibility complex (MHC) (Tian et al., 1992). It is thought that the MHC antigen is linked to the cell surface via glycosylphosphatidylinositol. Such a linkage may provide a mechanism for a transmembrane signal, as removal of the linkage slows development. In miniature pigs SLA ${ }^{2 / 3}$ and SLA ${ }^{c / c}$ embryos develop faster than do the SLA ${ }^{\mathrm{d} / \mathrm{d}}$ embryos (Ford et al., 1988). Such genetic differences in domestic pigs may account for some of the variation observed in the timing of blastocyst formation and elongation.

The duration of the one-cell stage, i.e. the first cell cycle, has been estimated as $15 \mathrm{~h}$ (Hunter, 1974). The duration of the two-cell stage, i.e. the second cell cycle, has been estimated as about $7 \mathrm{~h}$ in vivo (Hunter, 1974). However, in vitro, the two-cell stage is about $14 \mathrm{~h}$ (Stumpf et al., 1992). The Feulgen's reaction was used to quantitate the amount of DNA present at various times after cleavage to the twocell stage. Most of the cell cycle at the two-cell stage is composed of a DNA synthesis phase (S). It is difficult to conclude whether there is a gap phase $1(\mathrm{G} 1)$ or gap phase $2(\mathrm{G} 2)$ owing to the low sensitivity of the procedures. In contrast to the two-cell stage, the four-cell stage in vitro is about $50 \mathrm{~h}$ (Schoenbeck et al., 1992). The four-cell stage has a GI phase of less than $2 \mathrm{~h}$ and a DNA synthesis phase of $14-16 \mathrm{~h}$, followed by a G2 phase of about $34 \mathrm{~h}$. This $\mathrm{G} 2$ phase seems excessive and may be an in vitro induced artefact. In mice, in vitro conditions, mainly temperature variations, have been shown to result in protracted G2 phases, while not affecting the $S$ phase (Smith and Johnson, 1986). The estimated duration of the four-cell stage in vivo is $27 \mathrm{~h}$ (Hunter, 1974).

Although the Feulgen's stain (which quantitates DNA) provided some very important basic information regarding the $S$ phase, it did not provide precise timing as to the onset of DNA synthesis. Culture in the presence of $\left[{ }^{3} \mathrm{H}\right]$ thymidine followed by autoradiography (which indicates active DNA synthesis) was attempted; however, silver grains were never observed over the nuclei of two- or four-cell stage embryos that, based on the Feulgen data, should have been in $\mathrm{S}$ phase. In contrast, silver grains could routinely be observed over nuclei from blastocyst stage embryos (Fig. 1). Further precursor transport experiments determined that very little $\left[{ }^{3} \mathrm{H}\right]$ thymidine was transported across the plasma membrane of the two- or four-cell stage pig embryos. This is in contrast to the situation in mice (Luthardt and Donahue, 1973; R. A. Schoenbeck, M. S. Peters and R. S. Prather, unpublished) and rabbits (Collas et al., 1992), in which $\left[{ }^{3} \mathrm{H}\right]$ thymidine readily crosses the plasma membrane. It should be noted that some $\left[{ }^{3} \mathrm{H}\right]$ thymidine can apparently cross the plasma membrane of pig zygotes (Laurincik et al., 1993).

The duration of the eight-cell stage in vivo has been estimated as about $15 \mathrm{~h}$ (Hunter, 1974). In vivo, compaction begins at the late eight-cell stage (about $49 \mathrm{~h}$ after ovulation) and blastocyst formation occurs at the 32-cell stage (about $92 \mathrm{~h}$ after ovulation; Hunter, 1974).

\section{Ribonucleic Acid in the Early Pig Embryo}

\section{Maternal message}

During oocyte growth and development, in mice, all classes of RNA are transcribed and accumulate as stable mRNA (Ebert et al., 1984). During meiotic maturation about one third of the polyadenylated 

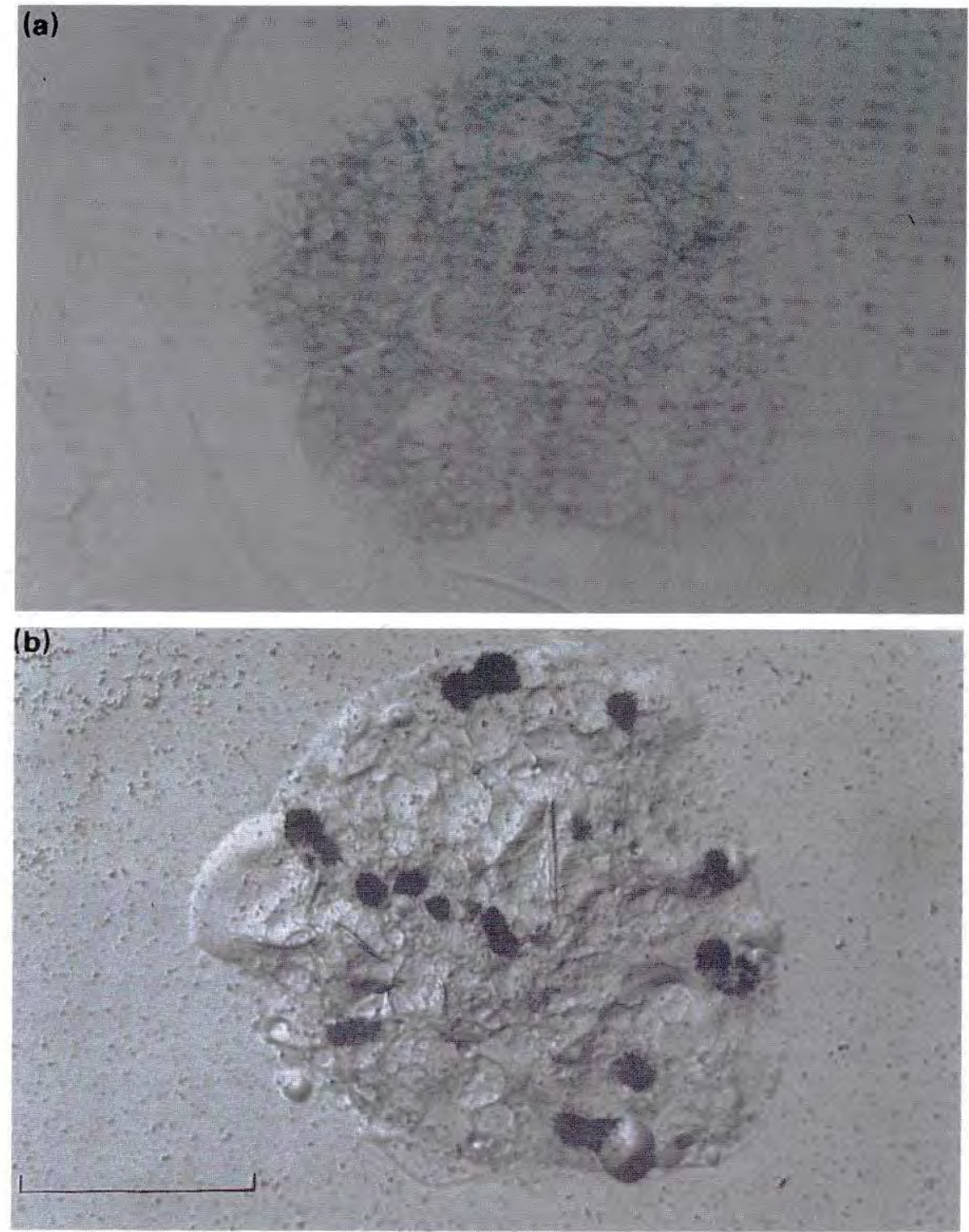

Fig. 1. Thymidine incorporation is shown. Pig embryos were cultured in the presence of $1 \mu \mathrm{mol}\left[{ }^{3} \mathrm{H}\right]$ thymidine $1^{-1}$ for $3 \mathrm{~h}$ during the time at which DNA synthesis was occurring during the four-cell stage and at the early blastocyst stage. The embryos were then subjected to autoradiography. (a) A four-cell stage embryo with no silver grains is shown, similar results were obtained with eight-cell stage embryos (not shown). In contrast, (b) shows silver grains over a number of nuclei of a blastocyst stage embryo. Silver grains were also obtained over nuclei with mouse pronuclear, two- and four-cell stage embryos (not shown).

RNA is either deadenylated or degraded (Bachvarova, 1981). During the two-cell stage, another $70 \%$ of the total polyadenylated and $90 \%$ of the histone and actin mRNA are degraded (reviewed by Schultz, 1986). This parallels the degradation seen with exogenously injected globin (Brinster et al., 1980), conalbumin and ovalbumin mRNA (Ebert et al., 1984). In addition, much of the remaining mRNA is in a form that cannot be translated. This may be due to a variety of factors. Fertilization causes polyadenylation, and polyadenylation may be necessary for ribosome association and subsequent translation. In sea urchins, RNA is uncapped before fertilization, but becomes capped at fertilization and is thus made 
available for processing (Caldwell and Emerson, 1985). In Xenopus mRNA-protein interactions may occur until specific cell stages, at which time the mRNA and proteins dissociate and are free to act upon the nucleus. Thus the RNA-protein complex may be able to regulate both transcription (the released protein interacting with the chromatin) and translation (the released mRNA interacting with the ribosomes; Crawford and Richter, 1987).

Indirect measurements in sheep, cows and pigs also suggest a fall in availability of maternal message at a species-specific cell stage. The amount of protein produced, as measured by incorporation of L$\left[{ }^{35}\right.$ S $]$ methionine by the eight-cell stage cow embryo is $68 \%$ of that of the zygote stage (Frei et al., 1989), whereas in sheep there is a dramatic decrease of $95 \%$ during the eight-cell stage (Crosby et al., 1988). In pigs, there is a $68 \%$ fall in protein produced from the zygote to the early four-cell stage and a $72 \%$ fall from the early four-cell stage to the late four-cell stage (Jarrell et al., 1991). Although these data suggest a reduction in availability of mRNA, they may simply be the result of differential L- $\left.{ }^{35} \mathrm{~S}\right]$ methionine transport (see below). Thus the question of availability of mRNA remains unanswered.

\section{RNA synthesis}

In a variety of species, early embryo development is characterized by cell cycles that have back-toback mitosis and $\mathrm{S}$ phases. This allows no gap phases for RNA polymerases to bind to the DNA for transcription to occur (Rivier and Rine, 1992). Thus early cleavage stages are characterized by the absence of RNA synthesis (Telford et al., 1990). Although RNA synthesis does occur during oocyte growth, it ceases at germinal vesicle breakdown. A few reports suggest that a very small amount of RNA synthesis may occur in zygotes (mouse: Clegg and Piko, 1982; human: Tesarik and Kopecny, 1989) and the bovine two- and four-cell stage (Viuff et al., 1992). The synthesis of significant amounts of RNA does not resume until a species-specific cell stage. In mice, the onset of synthesis of significant amounts of RNA occurs in the GI phase of the two-cell stage. At this time heat shock proteins (Bensuade et al., 1993), as well as a developmentally regulated transcription-requiring complex (Conover et al., 1991), are transcribed and subsequently translated. In pigs, transcription appears to begin during the four-cell stage, as evidenced by changes in nucleolar morphology, structure of the nuclear matrix, sensitivity to in vitro conditions, qualitative changes in protein synthesis, sensitivity to $\alpha$-amanitin and $\left[{ }^{3} \mathrm{H}\right]$ uridine incorporation (see below).

Direct measurement of $\left[{ }^{3} \mathrm{H}\right]$ uridine incorporation would be an obvious method for determining when RNA synthesis occurs in pigs. Although no incorporation can be detected during the zygote or two-cell stage, incorporation can be detected at the four-cell stage and increases 1000 fold by the blastocyst stage (Freitag et al., 1991). However, these data should be interpreted with caution since we (R. S. Prather, M. M. Sims and N. L. First, unpublished) have been unable to detect significant amounts of $\left[{ }^{3} \mathrm{H}\right]$ uridine transport in two-cell pig embryos (Fig. 2). It should be noted that although we used $1.6 \mu \mathrm{mol}\left[{ }^{3} \mathrm{H}\right]$ uridine $1^{-1}$. Freitag et al. (1991) used $9 \mu \mathrm{mol}\left[{ }^{3} \mathrm{H}\right]$ uridine $\mathrm{I}^{-1}$. Similar results of poor uridine transport also occur in mice (Clegg and Piko, 1982) and hamsters (Seshagiri et al., 1992). Thus it appears from the above data that the mechanism responsible for significant amounts of $\left[{ }^{3} \mathrm{H}\right]$ uridine transport in pigs first occurs during the four-cell stage. If little or no transport occurs at an earlier stage, thin measures of incorporation are meaningless.

It should be mentioned that $\left[{ }^{3} \mathrm{H}\right]$ uridine incorporation into the nuclei of two-cell stage pig embryos was reported by Hyttel et al. (1993). These data are difficult to reconcile with the previously reported information. It is possible that Hyttel et al. (1993) detected rRNA or tRNA synthesis because using identical procedures with bovine embryos labelling was not blocked by $\alpha$-amanitin (Viuff et al., 1992). It is also possible that early pig embryos are synthesizing precursor mRNA as in early rabbit embryos (see discussion in Telford et al., 1990), or that individual mRNA transcripts are not completely transcribed before mitosis occurs as in Drosophila (Thummel, 1992).

\section{Nucleolar morphology and $r R N A$ production}

The morphology and function of nucleoli change during embryogenesis in many species. In mice, the germinal vesicle oocyte synthesizes rRNA. However, rRNA synthesis ceases at germinal vesicle 


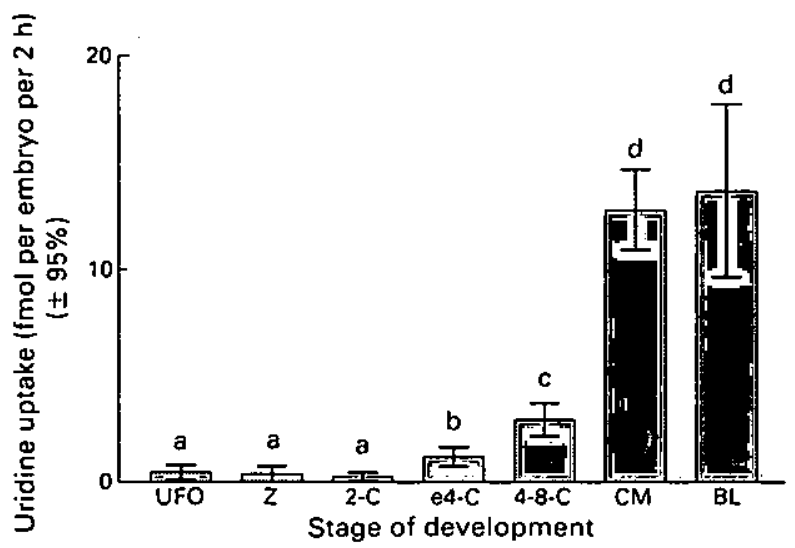

Fig. 2. Uptake of $\left[5,6-{ }^{3} \mathrm{H}\right]$ uridine during pig embryogenesis. UFO: unfertilized oocyte; $Z$ : zygote; $2-C$ : two-cell stage; e4-C: early four-cell stage; 4-8-C: late four-cell stage and eight-cell stage; CM: compact morula; $\mathrm{BL}$ : blastocyst were cultured in $1.6 \mu \mathrm{mol}\left[5,6-{ }^{3} \mathrm{H}\right]$ uridine $]^{-1}$ for $2 \mathrm{~h}$, then rinsed and radioactivity was measured. A pool of one to six oocytes per embryo was used per determination. Five to 20 determinations were made per cell stage. Confidence intervals (95\%) were constructed about each mean using the Student's $t$ test. Very little uptake was observed at the unfertilized oocyte and two-cell stage. The amount of uptake observed at the zygote stage was not different from zèro. Columns with different letters above are significantly different $(P<0.05)$. Uptake increases dramatically between the eight-cell stage and the compact morula stage (R. S. Prather, M. M. Sims and N. L. First. unpublished).

breakdown. Ribosomal RNA production cannot be detected at the pronuclear stage. The first positive detection of rRNA production is at the late two-cell stage (Piko and Clegg, 1982). The detection of rRNA production is correlated with the ultrastructure of the nucleoli. Nucleoli active in transcription, or definitive nucleoli, are characterized as being reticulated, having fibrillar cores and are surrounded by fibrillo-granular cortices (Hillman and Tasca, 1969). In mice, the oocyte at the germinal vesicle stage has definitive nucleoli, whereas after germinal vesicle breakdown, fertilization and pronuclear formation, there are no definitive nucleoli (Hillman and Tasca, 1969). The prenucleoli that appear at the pronuclear stage are composed of fine fibrils in a spherical centre surrounded by an agranular zone (Hillman and Tasca, 1969). Early in the first cell cycle prenucleoli are numerous and congregate during interphase, forming a single prenucleolus within each pronucleus prior to nuclear envelope breakdown (Prather et al., 1990). At the late two-cell stage, a single fibrillar prenucleolus begins to reticulate. This pattern of prenucleoli reticulating to form definitive nucleoli repeats itself at the four-cell stage forming two definitive nucleoli. By the eight-cell stage all nucleoli are reticulated, and thus are definitive nucleoli (Hillman and Tasca, 1969).

In pig embryos, definitive nucleoli are present in germinal vesicle oocytes (Norber, 1972; Crozet et al., 1981), but absent in pronuclear and two-cell stage embryos (Norberg, 1970, 1973a; Szollosi and Hunter, 1973). Four-cell stage nucleoli begin to associate with chromatin and reticulate (Norberg, 1970; Hyttel and Niemann, 1990) and become definitive nucleoli by the eight-cell stage (Norberg, 1973b; Tomanek et al, 1989). Tomanek et al. (1989) have shown that pig embryos do incorporate. $\left[{ }^{3} \mathrm{H}\right]$ uridine into nucleoli at the five- to eight-cell stage, but do not state whether the nucleoli that incorporate the uridine are four-cell stage blastomeres or eight-cell stage blastomeres. Their results should be interpreted with caution since uridine appears to be poorly transported in the early embryo (see above), and thus may not be readily available for incorporation into newly formed rRNA at earlier stages. 
Qualitative changes in protein synthesis

Qualitative changes in protein synthesis are seen during preimplantation embryo development in cows (four- to eight-cell stage: Frei et al., 1989; Barnes and First, 1991), sheep (eight- to 16-cell stage: Crosby et al., 1988) and humans (four- to eight-cell stage: Braude et al., 1988; Artley et al., 1992). Many of these changes in protein profiles are sensitive to $\alpha$-amanitin, which suggests embryonically directed transcription.

In pigs, the first qualitative change in protein production occurs at fertilization (Jarrell et al., 1991) and is the result of the dephosphorylation of a $26 \mathrm{kDa}$ protein (Ding et al, 1992). The next major qualitative change occurs during the four-cell stage and is sensitive to $\alpha$-amanitin (Jarrell et al., 1991). This qualitative change appears to occur between 12 and $16 \mathrm{~h}$ after cleavage (Schoenbeck et al., 1992) and corresponds well to the beginning of $\mathrm{G} 2$ (see above). These qualitative changes can be blocked with the addition of $\alpha$ amanitin, and thus suggest transcriptional dependence. Unfortunately, none of these proteins has yet been identified.

In addition to the qualitative changes seen during the four-cell stage, further changes in the types of protein produced are detected as the embryo undergoes compaction and blastocoel formation (Jarrell $e$ t al., 1991).

\section{Small nuclear ribonuclear proteins}

Small nuclear ribonuclear proteins (snRNPs) are responsible for processing pre-RNA into RNA. The more abundant snRNAs (U1, U2, U3, U4, U5, U6) are found in the nuclei of early mouse embryos (Lobo et al., 1988; Dean et al., 1989; Prather et al., 1990) and U2 snRNAs are found in the nuclei of early bovine embryos (Watson et al., 1992). These snRNAs are a carryover from maternally derived stores created during oogenesis. During the early cleavage period, the relative abundance of U1, U2, U3 and U6 does not increase uniformly (Lobo et al., 1988; Dean et al., 1989; Prather et al., 1990). A mouse monoclonal antibody (Y12) that precipitates the $B$ and $D$ core proteins of the snRNP, however, does not recognize antigens in early mouse and pig embryogenesis. In mice, the $\mathrm{Y}_{12}$ antigen is absent from pronuclei, but present in germinal vesicle and interphase nuclei at, and beyond, the two-cell stage (Stricker et al., 1989; Dean et al., 1989). Similarly, in cattle embryos, a marked increase in the labelling of nuclei with the Y12 antibody occurs coincidentally with the onset of RNA synthesis at the eight- to 16-cell stage (Kopecny et al., 1991; Kopecny and Fakan, 1992).

In pigs, the Y12 antigen is absent from both pronuclei and two-cell stage nuclei, but present in germinal vesicle and interphase nuclei at, and beyond, the four-cell stage (Prather and Rickords, 1992). The appearance of the Y12 antigen in mice and pigs at the two- and four-cell stage, respectively, is sensitive to $\alpha$-amanitin. Thus, the appearance of the $Y 12$ antigen is correlated with mRNA production and processing in mouse embryos and expected mRNA production and processing in pig embryos. However, cycloheximide treatment within $6 \mathrm{~h}$ after cleavage to the four-cell stage cannot block the appearance of $Y_{12}$ antigen in late four-cell stage pig embryos, suggesting that the $Y_{12}$ antigen might be maternally inherited, and its appearance may simply be due to its stabilization in the nuclear matrix at the onset of RNA production (Prather and Rickords, 1992). Alternatively, if there is a G1 phase, then mRNA and protein may have been produced before the addition of cycloheximide. This observation needs to be resolved. Similar changes in the nuclear matrix of mice are known to occur during the two-cell stage (Prather and Schatten, 1992, unpublished).

\section{Other changes that suggest new RNA synthesis in pigs}

Other indicators suggest new RNA synthesis at the four- to eight-cell stage. These include the detection of male specific antigens on the cell surface of eight-cell stage embryos (White et al., 1987), and the change in glucose metabolism (Flood and Wiebold, 1988) and $\beta$-galactosidase activity. The activity of $\beta$-galactosidase is low at the two- to four-cell stage, but increases 75 -fold by the blastocyst stage (Murnane et al., 1990). Unfortunately these investigators did not separate the two-cell data from the four-cell data. As an aside, this endogenous $\beta$-galactosidase activity may adversely affect gene transfer experiments that rely upon $\beta$-galactosidase activity as a marker. 
An in vitro induced artefact has been shown to occur at the cell stage where embryos from other species first begin producing RNA. This is the 'block' to development. In pigs this 'block' occurs during the four-cell stage (reviewed by Davis, 1985; Telford et al., 1990). Interestingly, the in vitro induced 'block' occurs in G2 of the cell cycle in pigs (Eyestone et al., 1986) after the qualitative change in protein profiles, (R. S. Prather, unpublished) as in mice (Bolton et al., 1984). This sensitivity to in vitro conditions may be due to a deficiency in the mechanism for $\mathrm{p} 34 \mathrm{cdc} 2$ protein kinase activation (Aoki et al., 1992) or overall protein synthesis rate (Anbari and Schultz, 1993). Thus the sensitivity to in vitro conditions is correlated with the cell stage mRNA production.

Spermine and spermidine synthesis are necessary for blastocoel formation in both mice and pigs. Spermine and spermidine interact with chromatin and affect differentiation in animals and plants (Heby, 1981). Inhibition of synthesis of polyamines with methylglyoxal-bis guanylhydrazone delays the normal uptake of $\left[{ }^{3}\right.$ H]uridine in mice (Alexandre and Gueskins, 1984) and reversibly delays formation of the blastocyst in both mouse and pig embryos (Alexandre and Gueskins, 1984; Lane and Davis, 1984; Zwierzchowski et al., 1986).

A final indicator that newly transcribed mRNA is necessary for development is the ability of $\alpha$ amanitin to block cleavage. If pig zygotes, two-cell or early four-cell stage embryos are placed in $\alpha$ amanitin, development does not proceed to the eight-cell stage Jarrell et al., 1991; Schoenbeck et al., 1992; R. S. Prather, unpublished). However, if four-cell stage embryos are placed in medium containing $\alpha$ amanitin $24 \mathrm{~h}$ after cleavage to the four-cell stage, development will proceed to the eight-cell stage (Schoenbeck et al., 1992). This finding suggests that, although some new transcription occurs before $16 \mathrm{~h}$ after cleavage to the four-cell stage, transcription necessary for cleavage to the eight-cell stage occurs only $24 \mathrm{~h}$ after cleavage to the four-cell stage. Likely candidates for the message produced more than $24 \mathrm{~h}$ after cleavage may include cyclin B or cdc25 (the Drosophila string gene).

Thus, it appears that germinal vesicle stage oocytes synthesize all classes of RNA. This transcription ceases at germinal vesicle breakdown and does not resume until the four-cell stage. Maternal RNA present at the early four-cell stage may be degraded. This degradation, in concert with post-translational modifications and newly synthesized RNA results in a qualitative change in protein production. The onset of RNA synthesis is correlated with changes in structure of the nucleolus and nuclear matrix, overall cellular metabolism and a sensitivity to conditions in vitro.

\section{Amino acid transport in mice and pigs}

Amino acid transport is facilitated by specific transporters within the plasma membrane of the cell. Different transport systems in the same cell type can be distinguished on the basis of their different, although sometimes overlapping, substrate selectivities. These transport systems have been classified according to their preference for anionic, cationic or zwitterionic amino acids and whether they are dependent upon external sodium. In the early mouse and rat embryo, the detection of some of these systems is developmentally regulated (Van Winkle, 1992). Although there are at least six systems for amino acid transport in mice that change in activity as preimplantation development proceeds, this discussion will focus upon only four of these systems.

The first transport systems to be discussed transport zwitterionic amino acids. System $L$ is sodiumindependent and selects for bulky zwitterionic amino acids such as leucine. System $\mathrm{B}^{\text {o.t }}$ is sodiumdependent and transports a broad scope of cationic, zwitterionic and bicyclic amino acids. In mice, the activity of system $\mathrm{L}$ gradually declines as the oocyte matures, is fertilized and develops to the blastocyst stage (Van Winkle et al., 1990a). In contrast, system $\mathrm{B}^{\mathrm{o}+\mathrm{+}}$ is not detected in unfertilized oocytes or zygotes. A small amount of activity can be detected at the two-cell stage (the time at which the mouse embryo begins producing is own RNA) and increases by the eight-cell stage. By the time the embryo develops to the blastocyst stage, the activity of system $B^{\text {o.t }}$ increases tenfold over the eight-cell stage (Van Winkle et al., 1990b).

As in mice, system L appears to be present in pig oocytes and early blastocysts (Prather et al., 1993a). However, in direct opposition to the order of developmental expression in mice, system $\mathrm{B}^{\mathbf{o}+}$ appears to be present in the oocyte, but not the blastocyst (Prather et al., 1993a). Thus, although mice provided a starting point for studies in pigs, the developmental regulation of system $\mathrm{B}^{\mathrm{o}+}$ is exactly the opposite of 


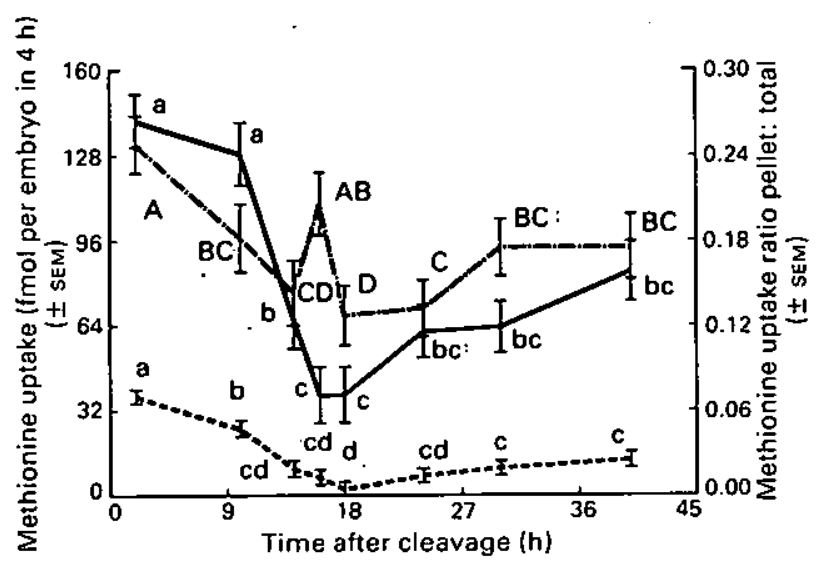

Fig 3. Methionine uptake and incorporation (adapted from Schoenbeck et al., 1993). Embryos were observed every $2 \mathrm{~h}$ for cleavage to the four-cell stage. At various times after cleavage, ten embryos were labelled with L- $\left.\right|^{35} S \mid$ methionine for $4 \mathrm{~h}$. The mean $( \pm$ SEM) of uptake $(-)$ and incorporation into protein (-----) are indicated (differences within uptake or within incorporation are denoted with different superscripts; ${ }^{2 b . c d} p<0.05$ ). The ratio of methionine uptake (pellet:total) is indicated ( \pm SEM) (-- $)$. Values with different superscripts are significantly different $(P<0.05)$.

what was expected. In pig oocytes and blastocysts, there is no evidence for the presence of systems $A$, ASC or $b^{0 .+}$. We will be testing the hypothesis that system $B^{0 .+}$ activity disappears during the four-cell stage, when a dramatic decline in L- $\left[{ }^{35}\right.$ S $]$ methionine uptake has been observed $16 \mathrm{~h}$ after cleavage to the four-cell stage (Fig. 3).

The next systems to be discussed are involved in transport of anionic amino acids. In the mouse system, $x_{c}^{-}$, a sodium-independent transporter, is present in the oocyte and its activity diminishes as the embryo develops (Van Winkle et al., 1992). The other transporter is system $\mathrm{X}_{\mathrm{AG}}{ }^{-}$, a sodium-dependent transporter, which is not detectable until after the eight-cell stage (Van Winkle et al., 1991). In contrast to the situation in mice, system $x_{c}{ }^{-}$cannot be detected in pig oocytes, and it was not detected in blastocyst stage embryos (Prather et al., 1993b). However, system $\mathrm{X}_{\mathrm{AC}}{ }^{-}$, although not detectable in oocytes, was detectable in early and hatched blastocysts (Prather et al., 1993b). Thus of the four systems characterized to date only two, system $\mathrm{L}$ and system $\mathrm{X}_{\mathrm{AC}}{ }^{-}$, are expressed in a developmental fashion similar to that in mice.

\section{Mitochondrial changes in early development}

The morphology of mitochondria differ depending upon the cell type, some are thin and filamentous, whereas others are spherical or highly branched. The mitochondria of early embryos of most domestic animals contain few cristae. In pig embryos, mitochondria assume a cortical location early in development, but become dispersed within the blastomeres as the embryo develops to the blastocyst stage. From the oocyte to eight-cell stage; mitochondria occur in small aggregates, and these aggregates are not seen in the trophoblast or inner cell mass of blastocysts. The aggregates, although appearing to be composed of many mitochondria, are in fact usually composed of a few mitochondria with a complex structure (Krause et al., 1992). Development of cristae in the mitochondria occurs as the pig embryo develops to the blastocyst stage (Hyttel and-Niemann, 1990; Krause et al., 1992). These mitochondrial changes during preimplantation development are temporally correlated with changes in glucose metabolism, respiration and RNA synthesis. 


\section{Maternal message degradation and a possible $G 1$ phase during the four-cell stage}

The evidence discussed above suggests that a dramatic change in mRNA production occurs at 14$16 \mathrm{~h}$ after cleavage to the four-cell stage, and that mRNA necessary for development beyond the four-cell stage was produced after $24 \mathrm{~h}$ after cleavage to the four-cell stage. These data call for two periods of $\mathrm{C}_{2}-$ directed mRNA synthesis ( $\mathrm{S}$ phase is completed by $16 \mathrm{~h}$ after cleavage). However, in an additional experiment, embryos were added to medium containing $\alpha$-amanitin at various times after cleavage to the four-cell stage, followed by labelling $24 \mathrm{~h}$ after cleavage to the four-cell stage with $\mathrm{L}-{ }^{35}{ }^{35}$ SImethionine. Uptake of $\mathrm{L}-\mathrm{L}^{35} \mathrm{~S}$ Imethionine is lowered $24 \mathrm{~h}$ after cleavage if the embryos are added to the $\alpha$-amanitin more than $4 \mathrm{~h}$ after cleavage to the four-cell stage (Schoenbeck et al, 1992). A possible explanation for this observation is the production of mRNA that signals the destruction of the maternal mRNA that code for amino acid transport proteins. In addition to the absolute uptake of $\mathrm{L}-\mathrm{I}^{35} \mathrm{~S}$ ] methionine, the production of maternal type proteins can be maintained if the embryos are cultured in $\alpha$-amanitin (Schoenbeck $e$ al., 1992). This result again suggests that mRNA production is necessary for the degradation of these maternal type RNAs that code for these proteins. These two experiments suggest that mRNA production occurs during a Gi phase of the four-cell stage.

In mice, a degradation of maternally derived mRNA occurs during the two-cell stage (see above). Similarly, in cows and sheep, it has been suggested that a decrease in availability of mRNA occurs during the stage at which the embryo begins RNA production (see above). Since both the amount of $\left.\mathrm{L}-\mathrm{I}^{35} \mathrm{~S}\right]$ methionine taken up by the four-cell stage pig embryo and the ratio of uptake to incorporation changes as the embryo progresses through the four-cell stage, it is likely that both degradation of preexisting transcripts occurs as well as a decrease in the transport of $\mathrm{L}-\left[{ }^{35} \mathrm{~S}\right]$ methionine across the plasma membrane.

Another suggestion of the degradation of maternally derived RNA comes from the loss of the maternal complement of $A / C$ type nuclear lamins after the two-cell stage in mice (Schatten et al., 1985) the four-cell stage in pigs (Prather et al., 1989a) and the eight- to 16-cell stage in cows (Prather et al., 1989a). If zygotic production of mRNA coding for the $A$ or $C$ lamins occurs, then lamins $A$ and $C$ should be detectable after the embryo begins producing its own RNA. Thus it appears that mRNA produced during $\mathrm{G} 1$ of the four-cell stage pig embryo directs the destruction of matemally derived mRNA.

\section{Mechanisms regulating the onset of RNA synthesis}

The overall regulation of the initiation of RNA synthesis in the early embryo still needs to be determined. The regulation of the timing of specific events in differentiation has generally been referred to as due to an intrinsic 'time clock'. This timing mechanism can be reset by nuclear transfer to an enucleated oocyte (Prather and Robl, 1991). Results from some previous studies using Xenopus embryos have suggested that the initiation of RNA synthesis is due to the change in the nuclear:cytoplasmic ratio; however, this needs to be re-evaluated (Lund and Dahlberg, 1992). There is also some evidence that cyclin B mRNA may be partially responsible for initiating transcription (Weeks et al., 1991). In other species, such as Drosophila, the duration of the cell cycle may reflect the time necessary for transcription to be completed, i.e. as the duration of the cell cycle increases then the genes that are physically longer are more likely to complete transcription before mitosis (Thummel, 1992). Unique combinations of these early genes could then act to promote expression of late genes.

In the mouse embryo, many events occur at a fixed time after fertilization. Transcription is independent of DNA synthesis (Poueymirou and Schultz, 1987), cell division (Petzoldt, 1984) and the nuclear: cytoplasmic ratio (Petzoldt and Muggleton-Harris, 1987). Enhancers are needed in the early mouse embryo to facilitate transcription (Martinez-Salas et al., 1989), owing to a general repression of transcription in the early zygote (Bonnerot et al., 1991) followed by a transcription permissive state (Latham et al., 1992). Initiation of transcription probably depends upon a cAMP-dependent protein kinase (PK-A) (Poueymirou and Schultz, 1989; Manejwala et al., 1991).

Factors that prevent transcription in the early mammalian embryo may include competition for promoter regions between DNA and RNA polymerases (Rivier and Rine, 1992), or between transcription factors and histone structure (Workman and Kingston, 1992). The latter explanation is supported by the 


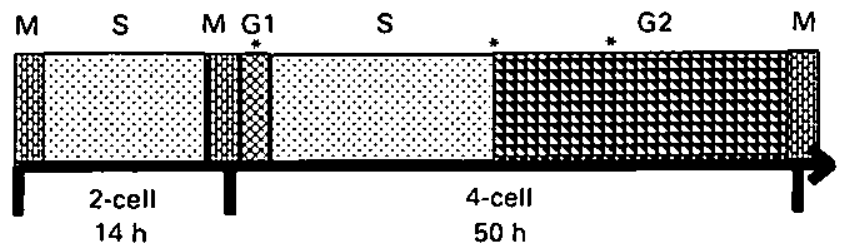

Fig. 4. An overview of the two- and four-cell stage pig embryo in vitro (M: mitosis; G1: gap phase 1; G2: gap phase 2; S: DNA synthesis). "Denotes $\alpha$-amanitin-sensitive event.

observation that there is a different type of DNA packaging, somatic histone $\mathrm{H} 1$ is not present, in the mouse zygote and two-cell stage embryo compared with other stages of development (Clark et al., 1992).

In comparison, very little is known about initiation of transcription and the regulation of developmental events in domestic pigs. It is known that some developmental events can be reprogrammed by nuclear transfer such as the timing of blastocoel formation (Prather et al, 1989b), the developmental appearance of an snRNP epitope (Prather and Rickords, 1992) and the disappearance of lamins $A / C$ (Prather et al., 1989a). If the mouse is a suitable model for initiation of transcription for pigs, then it appears that there may be a multitude of factors that prevent transcription in the zygote and two-cell stage pig embryo, followed by a transcription permissive period during the four-cell stage.

\section{Conclusions}

Pig zygote and two-cell stage embryos do not appear to synthesize significant amounts of mRNA and thus must rely upon matemally derived mRNA to direct development. The first indication of mRNA synthesis occurs during the GI phase of the four-cell stage, which is followed by $14-16 \mathrm{~h}$ of DNA synthesis. At the start of G2, a major qualitative change in protein synthesis occurs that is sensitive to $\alpha$-amanitin. Another $\alpha$-amanitin-sensitive event occurs beyond $24 \mathrm{~h}$ after cleavage to the four-cell stage. These three periods of mRNA synthesis during the four-cell stage may (1) cause degradation of preexisting mRNA, (2) cause a major onset of embryonically directed protein synthesis, and (3) result in transcripts necessary for cleavage to the eight-cell stage, respectively (see Fig. 4). A few characteristics that may be unique to the early pig embryo compared with many other mammals are (1) glucose and phosphate are not detrimental to development; (2) thymidine is transported across the plasma membrane very poorly; (3) the developmental appearance of amino acid transport systems is different; and (4) mRNA synthesis begins during the four-cell stage. The mechanisms regulating the timing of these events has yet to be elucidated.

This manuscript was prepared while the author was supported by Food for the $21^{\text {st }}$ Century and is a contribution from the Missouri Agriculture Experiment Station Journal Series number 11 879. The author wishes to thank S. Terlouw and his laboratory personnel for providing a constructive critique of this manuscript, and P. Hyttel for reviewing the manuscript and providing unpublished information.

\section{References}

Alexandre $\mathrm{H}$ and Cueskins $\mathrm{M}$ (1984) Relationship between the effects of polyamine depletion on DNA transcription and on blastocyst formation in the mouse Archives of Biology 95 $55-61$

Anbari K and Schultz RM (1993) Effect of sodium and betaine in culture media on development and relative rates of protein synthesis in preimplantation mouse embryos in vitro Molecular Reproduction and Development 35 24-28

Aoki F, Choi T, Mori M, Yamashita M, Nagahama $Y$ and Kohmoto K (1992) A deficiency in the mechanism for p34cdc2 protein kinase activation in mouse embryos arrested at 2-cell stage Developmental Biology 154 66-72

Artley JK, Braude PR and Johnson MH (1992) Gene activity and cleavage arrest in human pre-embryos Human Reproduction 7 1014-1021

Bachvarova R (1981) Synthesis, turnover, and stability of heterogeneous RNA in growing mouse oocytes Developmental Biology 86 384-392

Barnes FL and First NL (1991) Embryonic transcription in in vitro cultured bovine embryos Molecular Reproduction and Development 29 117-123 
Beckmann LS, Cantly TC, Rieke AR and Day BN (1990) Development and viability of one- and two-cell porcine embryos cultured through the 'four-cell block' Theriogenology 33193 (Abstract)

Bensuade O, Babinet C. Morange $M$ and Jacob F (1983) Heat shock proteins, first major products of zygotic gene activity in mouse embryos Nature 305 331-333

Bolton VN, Oades PJ and Johnson MH (1984) The relationship between cleavage, DNA replication and gene expression in the mouse 2-cell embryo Joumal of Embryology and Experimental Morphology 79 139-163

Bonnerot C, Vernet $M$, Grimber G, Briand P and Nicolas JF (1991) Transcriptional selectivity in early mouse embryos: a qualitative study Nucleic Acids Research 19 7251-7257

Braude P, Bolton V and Moore S (1988) Human gene expression first occurs between the four- and eight-cell stages of preimplantation development Nature 32 459-461

Brinster RL, Chen HY, Trumbauer ME and Avarbock MR (1980) Translation of globin messenger RNA by the mouse ovum Nahure 283 499-501

Caldwell DC and Emerson CP (1985) The role of cap methylation in the translational activation of stored matemal histone mRNA in sea urchin embryos Cell 42 691-700

Chatot CL. Ziomek CA, Bavister BD, Lewis JL and Torres I (1989) An improved culture medium supports development of random-bred 1-cell mouse embryos in vitro joumal of Reproduction and Fertility $86679-688$

Clark HJ, Oblin C and Bustin M (1992) Developmental regulation of chromatin composition during mouse embryogenesis: somatic histone $\mathrm{H}_{1}$ is first detectable at the 4-cell stage Development 115 791-799

Clegg KB and Piko L (1982) RNA synthesis and cytoplasmic polyadenylation in the one-cell mouse embryo Nature 295 342-345

Collas P, Balise JJ and Robl JM (1992) Influence of cell cycle stage of the donor nucleus on development of nuclear transplantation in rabbit embryos Biology of Reproduction 46 492-500

Conover JC, Temeles GL, Zimmermann JW, Burke B and Schuitz RM (1991) Stage-specific expression of a family of proteins that are major products of zygotic gene activation in the mouse embryo Developmental Biology 144 392-404

Crawford DR and Richter JD (1987) An RNA-binding protein forn Xenopus oocytes is associated with specific message sequences Development 101 741-749

Crosby IM, Gandolfi F and Moor RM (1988) Control of protein synthesis during early cleavage of sheep embryos foumal of Reproduction and fertility 82 769-775

Crozet N, Motlik J and Szollosi D (1981) Nucleolar fine structure and RNA synthesis in porcine oocytes during the early stages of antrum formation Biology of the Cell $\mathbf{4 1}$ $35-42$

Davis DL (1985) Culture and storage of pig embryos foumal of Reproduction and Fetility Supplement 33 115-124

Dean WL, Seufert AC, Schultz GA, Prather R, Simerly C, Schatten C, Pitch DR and Marzluff WF (1989) The small nuclear RNAs for pre-mRNA splicing are coordinately regulated during oocyte maturation and early embryogenesis in the mouse Development 106 325-334

Ding J, Clarke T, Nagai T and Moor RM (1992) Protein and nuclear changes in pig eggs at fertilization Molecular Reproduction and Development 31 287-296

Ebert KM. Paynton BV, McKnight GS and Brinster RL (1984) Translation and stability of ovalbumin messenger RNA injected into growing oocytes and fertilized ova of mice
Jounal of Embryology and Experimental Morphology 84 91-99

Ellington JE, Carney EW, Farrell PB, Simkin ME and Foote RH (1990) Bovine 1-2-cell embryo development using a simple medium in three oviduct epithelial cell coculture systems Biology of Reproduction 43 97-104

Eyestone WH. Lawyer ML, Critser ES and Leibfried-Rutledge ML (1986) Cell cycle stage of early porcine embryos during developmental arrest in vitro Biology of Reproduction 34 (Supplement) 98

Flood MR and Wiebold JL (1988) Glucose metabolism by preimplantation pig embryos Joumal of Reproduction and Fertility $847-12$

Ford SP, Schwartz NK, Rothschild MF, Conley AJ and Warner CM (1988) Influence of SLA haplotype on preimplantation embryonic cell number in miniature pigs Jounal of Reproduction and Fertility 84 99-104

Frei RE, Schultz GA and Church RB (1989) Qualitative and quantitative changes in protein synthesis occur at the 8to 16-cell stage of embryogenesis in the cow foumal of Reproduction and Fertility 86 637-641

Freitag M, Dopke HH, Niemann $H$ and Elsaesser F (1991) Ontogeny of RNA synthesis in preimplantation pig embryos and the effect of antioestrogen on blastocyst formation in vitro Molecular Reproduction and Development 29 I24-128

Hagen DR, Prather RS, Sims MM and First NL (1991) Development of one-cell porcine embryos to the blastocyst stage in simple media Jounal of Animal Science 69 1147-1150

Heby $O$ (1981) Role of polyamines in the control of cell proliferation and differentiation Differentialion 19 1-20

Hillman N and Tasca RJ (1969) Ultrastructural and autoradiographic studies of mouse cleavage stages American Journal of Anatomy 126 151-173

Hunter RHF (1974) Chronological and cytological details of fertilization and early embryonic development in the domestic pig Sus scrofa Anatomical Recond 178 169-185

Hyttel P and Niemann $H$ (1990) Ultrastructure of porcine embryos following development in vitro versus in vivo Molecular Reproduction and Development 27 136-144

Hyttel P, Prochazka R, Smith S, Kanka J and Greve T RNA synthesis in porcine blastomere nuclei introduced into in vitro matured ooplasm Acta Veterinaria Sandinavica (in press)

Jarrell VL, Day BN and Prather RS (1991) The transition from matemal to zygotic control of development occurs during the 4-cell stage in the domestic pig. Sus scrofa: quantitative and qualitative aspects of protein synthesis Biology of Reproduction $4462-68$

Krause WJ, Charlson EJ, Sherman DM and Day BN (1992) Three-dimensional reconstruction of mitochondrial aggregates in porcine oocytes, zygotes and early embryos using a personal computer Zoologischer Anzeiger 229 21-36

Kopecny V and Fakan ST (1992) Extranucleolar genome reactivation: topochemical studies on early bovine embryo: a review Acta Histochemica Supplement XLII, S301-309

Kopecny V. Fakan S, Pavlok A, Pivko J, Grafenau P. Biggiogera $M$, Leser $G$ and Martin TE (1991) Immunoelectron microscopic localization of small nuclear ribonucleoproteins during bovine early embryogenesis Molecular Reproduction and Development 29 209-219

Lane SM and Davis DL (1984) Regulation of embryo development in pigs: effect of inhibiting polyamine synthesis journal of Animal Science 59 (Supplement 1) 122 
Latham KE, Soltor D and Schultz RM (1992) Acquisition of a transcriptionally permissive state during the 1-cell stage of mouse embryogenesis Developmental Biology 149 457-462

Laurincik J, Kopecny V and Hyttel P (1993) Pronucleus development and DNA synthesis in in vivo produced porcine zygotes Theriogenology 39254 (Abstract)

Lobo SM, Marzluff WF, Seufert AC, Dean WL, Schultz GA, Simerly C and Schatten G (1988) Localization and expression of U1 RNA in early mouse embryo development Developmental Biology 127 349-361

Lund E and Dahlberg JE (1992) Control of 4-8S RNA transcription at the midblastula transition in Xenopus laevi embryos Genes and Development 6 1097-1106

Luthardt FW and Donahue RP (1973) Pronuclear DNA synthesis in mouse eggs Experimental Cell Research 82 143-151

Mancjwala FM, Logan CY and Schultz RM (1991) Regulation of hsp70 mRNA levels during oocyte maturation and zygotic gene activation in the mouse Developmental Biology 144 301-308

Martinez-Salas E, Linney E. Hassell J and DePamphilis ML. (1989) The need for enhancers in gene expression first appears during mouse development with formation of the zygotic nucleus Genes and Development 3 I493-1506

Mumane RD, Wright RW Jr, Hoffmann KA and Prieur DJ (1990) Expression of $\beta$-galactosidase in preimplantation ovine and porcine embryos Proceedings of the Society of Experimental Biology and Medicine 194 144-148

Norberg HS (1970) Nucleosphaeridies in early pig embryos Zeitschrift fur Zellforsch und Mikroskopische Analomie 110 61-71

Norberg HS (1972) The follicular oocyte and its granulosa cells in domestic pigs Zeilschnift fur Zellforsch und Mikroskopische Anatomie 131 497-517

Norberg HS (1973a) Ultrastructure of pig tubal ova Zeitschrift fur Zellforsch utd Microskopische Anatomie 141 103-122

Norberg HS (1973b) Ultrastructural aspects of the preattached pig embryo: cleavage and early blastocyst stages Zeitsclirift fur Anatomie Entwicklongsgeschichte 143 95-114

Petters RM, Johnson BH, Reed ML, and Archibong AE (1990) Glucose, glutamine and inorganic phosphate in early development of the pig embryo in vitro Jounal of Reproduction aud Fertility 89 269-275

Petzoldt U (1984) Regulation of stage-specific gene expression during early mouse development: effect of cytochalasin B and aphidicolin on stage-specific protein synthesis in mouse eggs Cell Differentiation 15 163-167

Petzoldt $U$ and Muggleton-Harris A (1987) The effect of the nucleocytoplasmic ratio on protein synthesis and expression of stage-specific antigen in early cleaving mouse embryos Development $99481-49$ I

Piko L and Clegg KB (1982) Quantitative changes in total RNA, total poly(A) and ribosomes in early mouse embryos Developmental Biology 89 362-378

Poueymirou WT and Schultz RM (1987) Differential effects of activators of CAMP-dependent protein kinase and protein kinase $C$ on cleaveage of one-cell mouse embryos and protein synthesis and phosphorylation in one- and two-cell embryos Developmental Biology 121 568-575

Poueymirou WT and Schultz RM (1989) Regulation of mouse preimplantation development: inhibition of synthesis of proteins in the two-cell embryo that require transcription by inhibitors of CAMP-dependent protein kinase Developmental Biology 133 588-599

Prather RS and First NL (1988) A review of early mouse embryogenesis and its applications to domestic animals Journal of Animal Science $662626-2635$
Prather RS and Rickords LF (1992) Developmental regulation of an snRNP core protein epitope during pig embryogenesis and after nuclear transfer for cloning Molectular Reproduction and Development 33 119-123

Prather RS and Robl JM (1991) Cloning by nuclear transfer and embryo splitting in laboratory and domestic animals. In Animal Applications of Research in Mammalian Development, Current Communications in Cell and Molectuar Biology Vol. 4 pp 205-232 Eds R A Pederson, A McLaren and N L First. Cold Spring Harbor Laboratory Press, New York

Prather RS and Schatten C (1992) Construction of the nuclear matrix at the transition from matemal zygotic control of development in the mouse: an immunocytochemical study Molecular Reproduction and Development 32 203-208

Prather RS, Sims MM, Maul GG, First NL, and Schatten G (1989a) Nuclear lamin antigens are developmentally regulated during porcine and bovine embryogenesis Biology of Reproduction 41 123-132

Prather RS, Sims MM and First NL (1989b) Nuclear transplantation in early pig embryos Biology of Reproduction 41 414-418

Prather R, Simerly C, Schatten G, Pilch DR, Lobo SM, Marzluff WF. Dean WL and Schuitz CA (1990) U3 snRNPs and nucleolar development during oocyte maturation, fertilization and early embryogenesis in the mouse: U3 snRNA and SnRNPs are not regulated coordinate with other snRNAs and snRNPs Developmental Biology 138 247-255

Prather RS, Peters MS and Van Winkle LJ (1993a) Alanine and leucine transport in unfertilized pig oocytes and early blastocysts Molecular Reproduction and Development 34 250-254

Prather RS, Peters MS and Van Winkle LJ (1993b) Aspartate and glutamate transport in unfertilized pig oocytes and blastocysts 36 49-52

Reed ML, Illera MJ and Petters RM (1992) In vitro culture of pig embryos Theriogenology 37 95-109

Rivier DH and Rine J (1992) An origin of DNA replication and a transcription silencer require a common element Science 256 659-663

Schatten G, Maul GG, Schatten H, Chaly N, Simerly C, Balczon R and Brown DL (1985) Nuclear lamins and peripheral nuclear antigens during fertilization and embryogenesis in mice and sea urchins Proceedings of the National Academy of Sciences USA 82 4727-4731

Schini SA and Bavister BD (1988) Two-cell block to development of cultured hamster embryos is caused by phosphate and glucose Biology of Reproduction 39 1183-1192

Schoenbeck RA, Peters MS, Rickords LF, Stumpf TT and Prather RS (1992) Characterization of DNA synthesis and the transition from maternal to embryonic control in the 4-cell porcine embryo Biology of Reprotuction 47 1118-1125

Schultz. GA (1986) Molecular biology of the early mouse embryo Biological Bulletin 171 291-309

Seshagiri PB, McKenzic DI, Bavister BD. Williamsin JL and Aiken JM (1992) Golden hamster embryonic genome activation occurs at the two-cell stage: correlation with major developmental changes Molecular Reproduction and Development 32 229-235

Smith RKW and Johnson MH (1986) Analysis of the third and fourth cell cycles of mouse early development joumal of Reproduction and Fertility 76 393-399

Stricker S, Prather R, Simerly C, Schatten H and Schatten G (1989) Nuclear architectural changes during fertilization and development. In The Cellular Biology of Fertilization pp 323340 Eds $\mathrm{H}$ Schatten and $G$ Schatten. Academic Press, Orlando 
Stumpf rT, Schoenbeck RA and Prather RS (1992) DNA synthesis during the porcine embryo two-cell stage Biology of Reproduction 46 (Supplement 1) 71

Szollosi and Hunter RHF (1973) Ultrastructural aspects of fertilization in the domestic pig: sperm penetration and pronucleus formation Joumal of Anatomy 116 181-206

Telford NA, Watson AJ and Schultz GA (1990) Transition from maternal to embryonic control in early mammalian development: a comparison of several species Molecular Reproduction and Development 26 90-100

Tesarik J and Kopecny V (1989) Nucleic acid synthesis and development of human male pronucleus joumal of Reproduction and Fertility 86 549-558

Thummel CS (1992) Mechanisms of transcriptional timing in Drosophila Science 255 39-40

Tian Z, Yuanxin X and Warner CM (1992) Removal of Qa-2 antigen alters the Ped gene phenotype of preimplantation mouse embryos Biology of Reproduction 47 271-276

Tomanek M, Kopency V and Kanka J (1989) Genome reactivation in developing early pig embryos: an ultrastructural and autoradiographic analysis Anatomy and Embryology 180 309-316

Van Winkle LJ (1992) Amino acid transport during embryogenesis. In Mammalian Amino Acid Transpori: Mechanisms and Control Eds MS Kilberg and D Haussinger. Plenum Press, New York

Van Winkle LJ, Campione AL, Gorman JM and Weimer BD (1990a) Changes in the activities of amino acid transport systems $b^{a+}$ and $L$ during development of preimplantation mouse conceptuses Biochimica et Biophysica Acta 1025 215-224

Van Winkle LJ, Campione AL and Farrington BH (1990b) Development of system $\mathrm{B}^{\mathrm{a}}$ and a broad-scope $\mathrm{Na}^{+}$. dependent transporter of zwitterionic amino acids in preimplantation mouse conceptuses Biochimica et Biophysion Acta 1025 225-233

Van Winkle LJ, Mann DF, Weimer BD and Campione AL (1991) $\mathrm{Na}^{+}$-dependent transport of anionic arnino acids by preimplantation mouse blastocysts Biochimica et Biophysica Acta $1068231-236$

Van Winkle LJ, Mann DF, Wasserlauf HG and Patel M (1992) Mediated $\mathrm{Na}^{+}$-independent transport of $\mathrm{L}$-glutamate and $\mathrm{L}$ cystine in 1- and 2-cell mouse conceptuses Biochimica et Biophysica Acia 1107 299-304

Viuff D, Avery B, Hyttel P and Greve T (1992) Onset of RNA synthesis in bovine embryos produced in vitro 12 th Intermational Congress on Animal Reproduction The Hague. The Netherlands, p 1369. Gregorius, Zeist

Watson AJ, Wiemer KE, Arcellana-Panlilo M and Schultz G - (1992) U2 small nuclear RNA localization and expression during bovine preimplantation development Molecular Reproduction and Development 31 231-240

Weeks DL. Walser JA and Dayle JM (1991) Cyclin B mRNA depletion only transiently inhibits the Xenopus embryonic cell cycle Development 111 1173-1178

White KL, Anderson GB and Pashen RL (1987) Identification of a male-specific histocompatibility protein on preimplantation porcine embryos Gamete Research 17 107-113

Workman JL and Kingston RE (1992) Nucleosome core displacement in vitro via a metastable transcription factor-nucleosome complex Science 258 1780-1784

Zwierzchowski L, Czlonkowska M and Guszkiewic A (1986) Effect of polyamine limitation on DNA synthesis and development of mouse preimplantation embryos in vitro Joumal of Reproduction and Fertility 76 115-121 